Article

\title{
Genetic and Neurological Deficiencies in the Visual System of mct8 Mutant Zebrafish
}

\author{
Rotem Rozenblat ${ }^{1,2}$, Adi Tovin ${ }^{1}$, David Zada ${ }^{1,2}$, Ilana Lebenthal-Loinger ${ }^{1}$, Tali Lerer-Goldshtein ${ }^{1,2}$ \\ and Lior Appelbaum $1,2, *$ (D)
}

1 The Faculty of Life Sciences, Bar-Ilan University, Ramat-Gan 5290002, Israel; rotemroze@gmail.com (R.R.); aditovin@gmail.com (A.T.); david.zada85@gmail.com (D.Z.); ilanalebenthal@gmail.com (I.L.-L.); tali.lerer@gmail.com (T.L.-G.)

2 The Multidisciplinary Brain Research Center, Bar-Ilan University, Ramat-Gan 5290002, Israel

* Correspondence: lior.appelbaum@biu.ac.il; Tel.: +972-3-7384536

Citation: Rozenblat, R.; Tovin, A.; Zada, D.; Lebenthal-Loinger, I.; Lerer-Goldshtein, T.; Appelbaum, L. Genetic and Neurological

Deficiencies in the Visual System of mct8 Mutant Zebrafish. Int. J. Mol. Sci. 2022, 23, 2464. https://doi.org/ $10.3390 /$ ijms 23052464

Academic Editor: Heike Heuer

Received: 27 January 2022

Accepted: 20 February 2022

Published: 23 February 2022

Publisher's Note: MDPI stays neutral with regard to jurisdictional claims in published maps and institutional affiliations.

Copyright: (C) 2022 by the authors. Licensee MDPI, Basel, Switzerland. This article is an open access article distributed under the terms and conditions of the Creative Commons Attribution (CC BY) license (https:// creativecommons.org/licenses/by/ $4.0 /)$

\begin{abstract}
Thyroid hormones (THs; T3 and T4) enter cells using specific transporters and regulate development and metabolism. Mutation in the TH transporter monocarboxylate transporter 8 (MCT8, SLC16A2) is associated with brain hypothyroidism and neurological impairment. We established mct8 mutant ( $m c t 8-/-)$ zebrafish as a model for MCT8 deficiency, which causes endocrinological, neurological, and behavioral alterations. Here, we profiled the transcriptome of $m c t 8-/-$ larvae. Among hundreds of differentially expressed genes, the expression of a cluster of vision-related genes was distinct. Specifically, the expression of the opsin 1 medium wave sensitive 2 (opn1mw2) decreased in two $m c t 8$ mutants: $m c t 8-/-$ and $m c t 8^{-25 b p}-/$ - larvae, and under pharmacological inhibition of $\mathrm{TH}$ production. Optokinetic reflex (OKR) assays showed a reduction in the number of conjugated eye movements, and live imaging of genetically encoded $\mathrm{Ca}^{2+}$ indicator revealed altered neuronal activity in the pretectum area of $m c t 8^{-25 b p}-/$ - larvae. These results imply that MCT8 and THs regulate the development of the visual system and suggest a mechanism to the deficiencies observed in the visual system of MCT8-deficiency patients.
\end{abstract}

Keywords: thyroid hormones; monocarboxylate transporter 8; opsin; zebrafish; OKR; pretectum

\section{Introduction}

Insufficient production of the thyroid hormones (THs), triiodothyronine (T3) and thyroxine (T4), and altered TH transport into the cells during prenatal and postnatal periods causes profound neurodevelopmental disorders [1,2]. In the nervous system, THs primarily regulate terminal neuronal differentiation processes, such as dendritic and axonal growth, synaptogenesis, cell migration, and myelination [3,4]. Several transmembrane $\mathrm{TH}$ transporters have been functionally described, including the monocarboxylate transporter 8 (MCT8) [5,6]. The critical role of MCT8 in regulating TH signaling, metabolism, and brain development is evident by the symptoms of the X-linked inherited Allan-HerndonDudley syndrome (AHDS/MCT8-deficiency) associated with mutations in the MCT8 (SLC16A2) gene. MCT8-deficiency is characterized by severe cognitive deficits, spastic quadriplegia, hypotonia, and elevated serum $\mathrm{T} 3$ levels $[7,8]$. Notably, abnormal conjugating eye movements and strabismus were also diagnosed in the patients [6,8,9], suggesting an altered visuomotor function in MCT8-deficient patients.

The visual system includes retinal photoreceptors, which are specialized cells that house light-sensitive visual pigments called opsins. Opsins are integral membrane proteins covalently linked to a light-sensitive vitamin A-based chromophore [10]. The opsin family is highly conserved across phylogeny and isolated in animals, ranging from cnidarians to primates [11]. In rodents, THs regulate the expression and differentiation of opsins in the visual system [12,13]. Similarly, in human organoids, THs regulate photoreceptor subtype specification [14]. These findings suggest that abnormal cellular transport of THs can affect 
the expression and function of opsins and the development of the visual system in MCT8 deficiency.

To study the mechanism of MCT8 deficiency, several mouse models have been generated and extensively studied [15-20]. A complementary animal model is the zebrafish, which is a simple vertebrate with a conserved organization of the central nervous system (CNS) and the hypothalamus-pituitary-thyroid gland axis [21,22]. Similar to mammals, THs are essential for the development and function of zebrafish, and the lack of endogenous and maternal TH impairs neuronal development in embryos [23]. We generated mct8 mutant $(m c t 8-/-)$ zebrafish. The transparent nature of the $m c t 8-/-$ larvae enabled revealing a wide range of neurological and behavioral deficits, including hypomyelination, reduced axonal branching and synaptic density, altered locomotor activity, and sleep [24-26]. However, the role of Mct8 in regulating the function of the visual system is unclear. Here, we performed whole transcriptome sequencing, TH-related pharmacological assays, and time-lapse imaging of neuronal activity and behavior to characterize genetic and neuronal alterations in $m c t 8-/-$ larvae, with special emphasis on the visual system.

\section{Results}

\subsection{Profiling the Transcriptome of mct8-/- Larvae Revealed Altered Expression of Visual} System Genes

Loss of function of MCT8 affects TH transport and the expression of numerous genes in vertebrates [27-29]. To profile the transcriptome of the zebrafish model for MCT8 deficiency, we performed RNA-seq in 6 days post-fertilization (dpf) mct8-/- larvae and their wild-type (WT) siblings. Differentially expressed genes were determined using the DESeq R Bioconductor package, with a criterion of $-1<\log 2$ (fold change) $<1$ and adjusted $p$-value ( $p$-adj) $<0.05$. The analysis identified 97 and 204 up-regulated (Table S1) and down-regulated (Table S2) genes, respectively, in mct8 - / - larvae (Figure 1A). To identify and classify specific genetic pathways, we utilized the Ingenuity Pathway Analysis (IPA) software and found 23 significantly enriched canonical pathways ( $p$-adj $\leq 0.05)$. Among these pathways, prominent alterations were found in visual-system-related pathways, such as the visual cycle, retinoate biosynthesis II and phototransduction (Figure 1B). In addition, marked enrichment was found in the VDR/RXR activation pathway, which includes vitamin D receptor-related genes, and is related to hypothyroid diseases [30]. Additional enriched processes include the DNA double-strand break repair and the tetrahydrobiopterin biosynthesis pathways [31]. Taking into account the prominent alteration in the visual system pathways, we profiled the expression of some of the visual genes that are related to these pathways (Figure 1C). The expression of the long-wave-sensitive 1 opsin 1 (opn1lw1) and medium-wave-sensitive 2 opsin 1 (opn1mw2) were reduced by 4.35 -fold $\left(p\right.$-adj $\left.=1.89 \times 10^{-7}\right)$ and 5.52 -fold $\left(p\right.$-adj $\left.=3.72 \times 10^{-65}\right)$, respectively. The expression of the retinol-binding protein 1 ( $r b p 1)$ and cone photoreceptor cyclic nucleotide-gated channel alpha 3 (cnga3) was reduced by 2.06 -fold ( $p$-adj $\left.=9.78 \times 10^{-22}\right)$ and 2.05 -fold $\left(p\right.$-adj $\left.=1.6 \times 10^{-24}\right)$, respectively (Figure $\left.1 C\right)$.

Next, we validated the transcriptome results in selected genes of interest using quantitative real-time PCR (qRT-PCR) on cDNA produced from separate batches of $6 \mathrm{dpf}$ $m c t 8-/-$ larvae and their WT siblings. The expression of the DNA repair gene rad51 and the structural chromatin modulator hdac10 was up-regulated by 3.76-fold $(p=0.002)$ and down-regulated by 4.54 -fold $\left(p=1.36 \times 10^{-5}\right)$, respectively. In addition, the expression of the voltage-gated potassium channel $k c n v 2 b$ was reduced by 3.45 -fold $\left(p=8.52 \times 10^{-8}\right)$, while the expression of the axon guidance regulator draxin did not change (Figure 1D). Taken together, these results identified dozens of differentially expressed genes in various pathways, including the visual system in $m c t 8-/-$ larvae. 

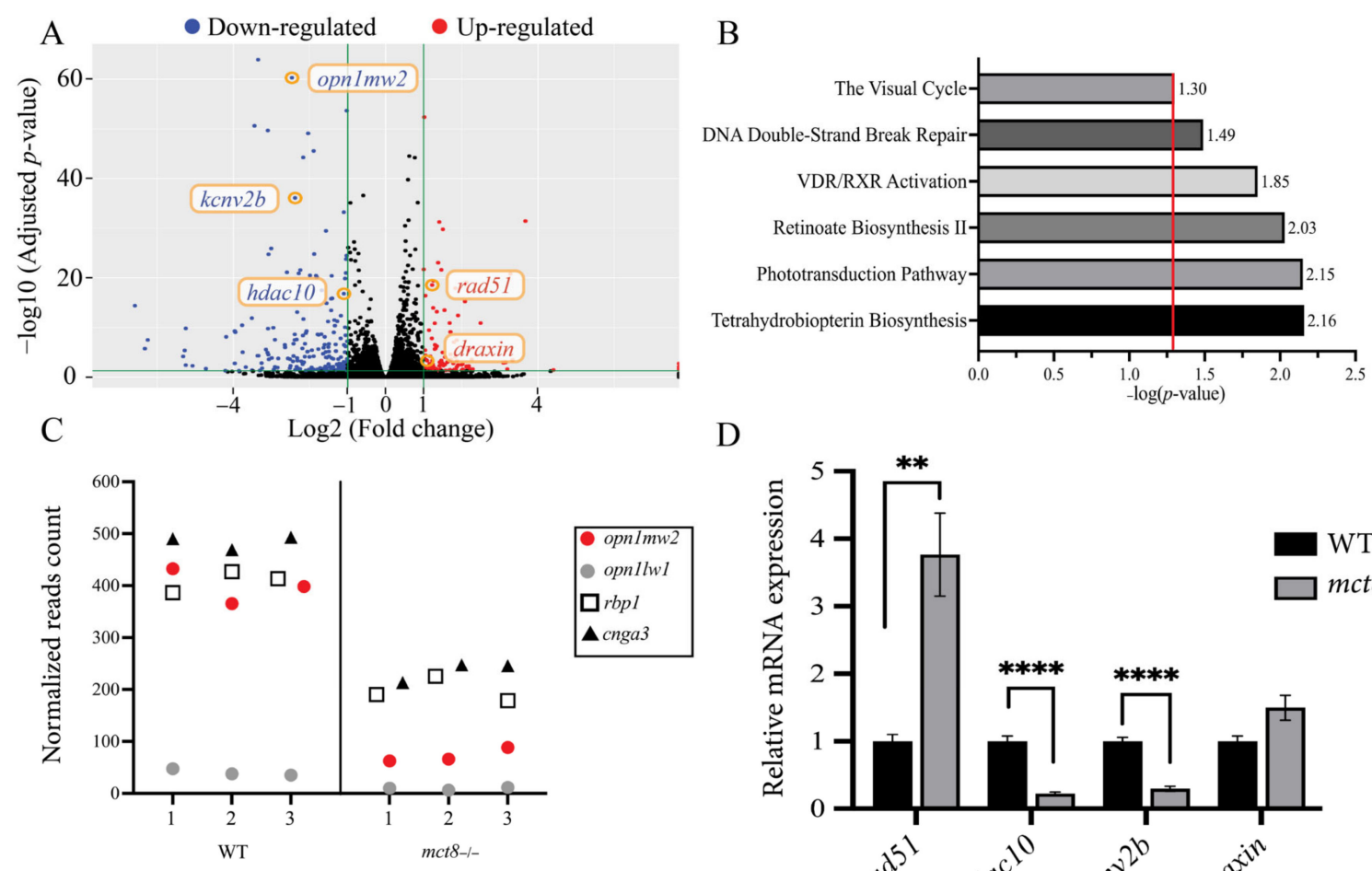

D

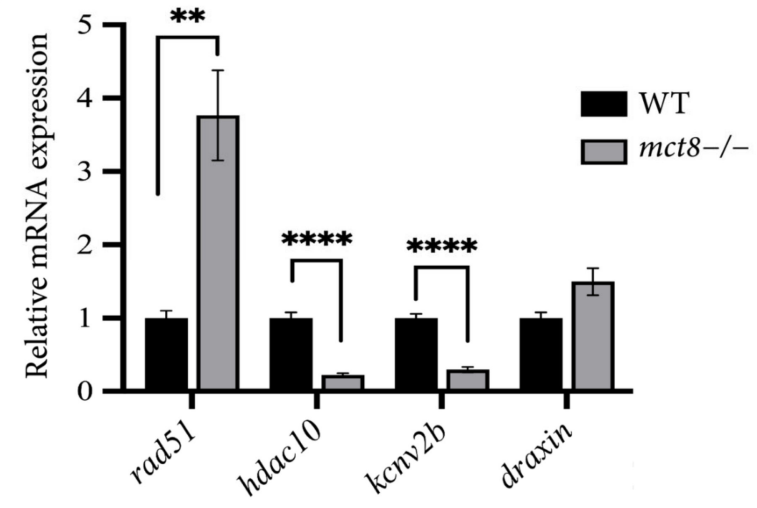

Figure 1. Transcriptome profiling in mct8-/ - larvae. (A) Differentially expressed genes in 6 days post-fertilization (dpf) $m c t 8-/-$ and wild-type (WT) sibling larvae ( $n=3$ batches for each genotype). Green vertical lines differentiate between significant and insignificant expressed genes. Blue and red dots mark down-regulated and up-regulated genes $(1<\log 2$ [fold change] $<1$, adjusted $p$-value $(p$-adj $<0.05)$, respectively. Black dots mark insignificant expressed genes. Orange circles mark genes validated by qRT-PCR. (B) Representative enriched gene pathways in $m c t 8-/-$ larvae. The red vertical line marks the threshold of significantly enriched pathways ( $p$-adj $\leq 0.05)$. (C) Normalized reads count of four differentially expressed genes selected from the enriched vision pathways shown in B. X-axis represents the sample number in each genotype. (D) Relative gene expression of selected genes was quantified using qRT-PCR and normalized against $a c t b$ ( $n=5$ batches of larvae for each group). Statistical significance determined by $t$-test: two-sample. ${ }^{* *} p<0.01,{ }^{* * * *} p<0.0001$.

\subsection{The Expression of opn1mw2 Is Reduced in mct8-/- Larvae and Is Regulated by THs}

The transcriptome data showed robust reduction in the expression of the vision-related gene opn1mw2. In order to study the effect of MCT8-deficiency on the expression of opn1mw2 during zebrafish development, we monitored the spatial expression pattern of opn1mw2, using in situ hybridization (ISH), in WT and mct8-/ - larvae. At $3 \mathrm{dpf}$, the expression of opn1mw2 reduced in the forebrain and predominantly in the retina of $m c t 8-/-$ larvae (Figure 2A-D). To study the dynamic expression of opn1mw2 along development, qRT-PCR assays were performed. The levels of opn1mw2 mRNA reduced by 1.78-, 2.94-, and 6.66-fold in 3, 4, and $6 \mathrm{dpf} m c t 8-/-$ larvae, respectively (Figure 2E). To verify the specificity of this phenotype to $m c t 8$, we reevaluated these results in additional mct8 mutant $\left(m c t 8^{-25 b p}-/-\right)$ larvae. This mutant, which harbors a $25 \mathrm{bp}$ deletion in exon 3, demonstrated a 2.77-fold reduction in the expression of opn1mw2 in $6 \mathrm{dpf}$ larvae (Figure 2F), as was the case in mct $8-/-$ larvae. Furthermore, microinjection of mct $8 \mathrm{mRNA}$ at one-cell stage rescued and normalized the expression of opn1mw2 in $3 \mathrm{dpf} m c t 8-/-$ embryos (Figure $2 \mathrm{G}$ ). These results show that Mct8 mediates opn1mw2 expression. 


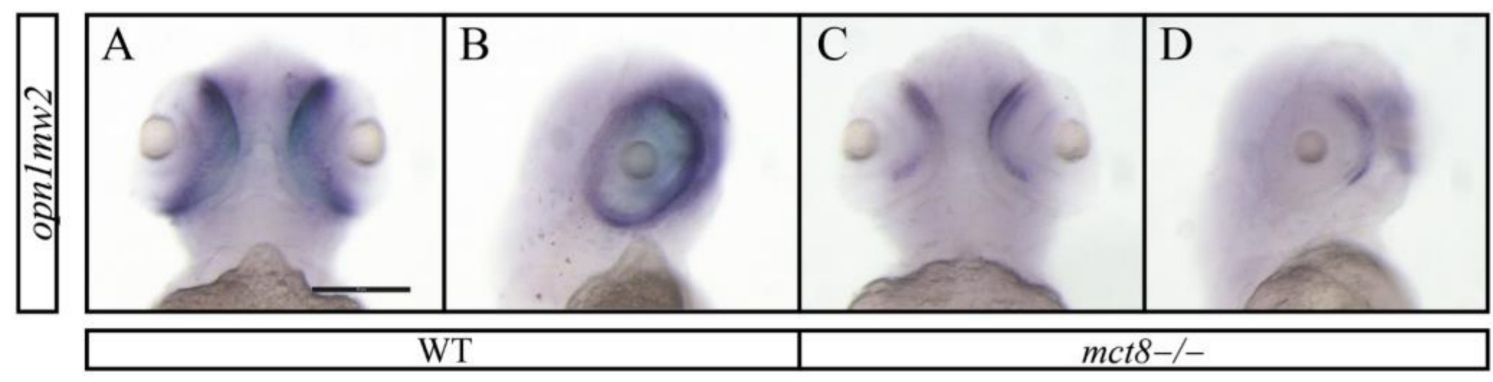

E

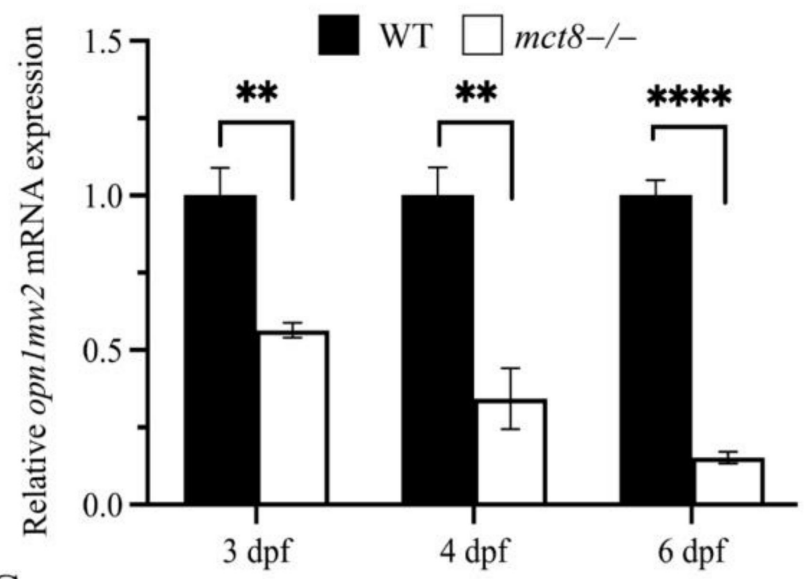

G
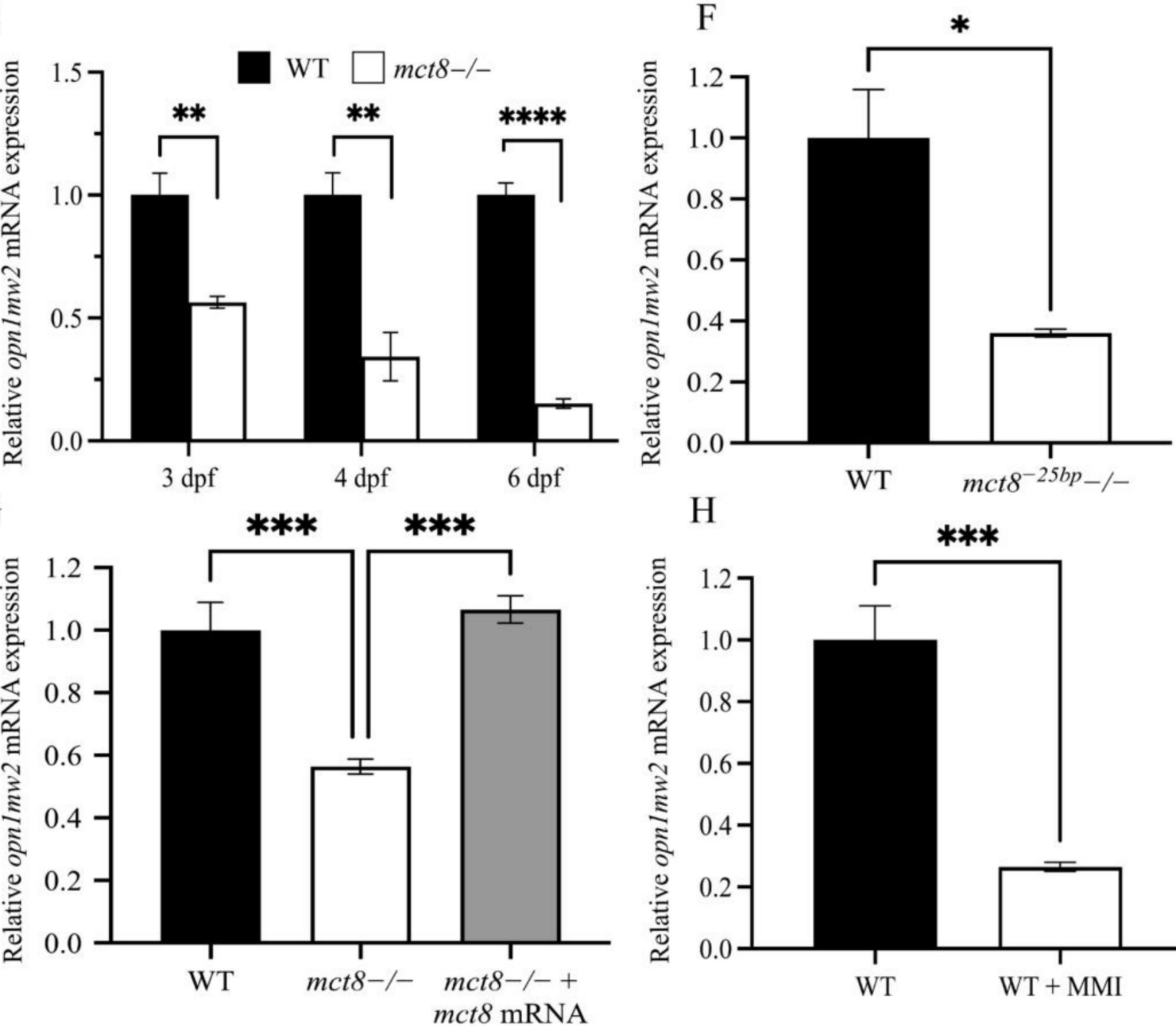

H

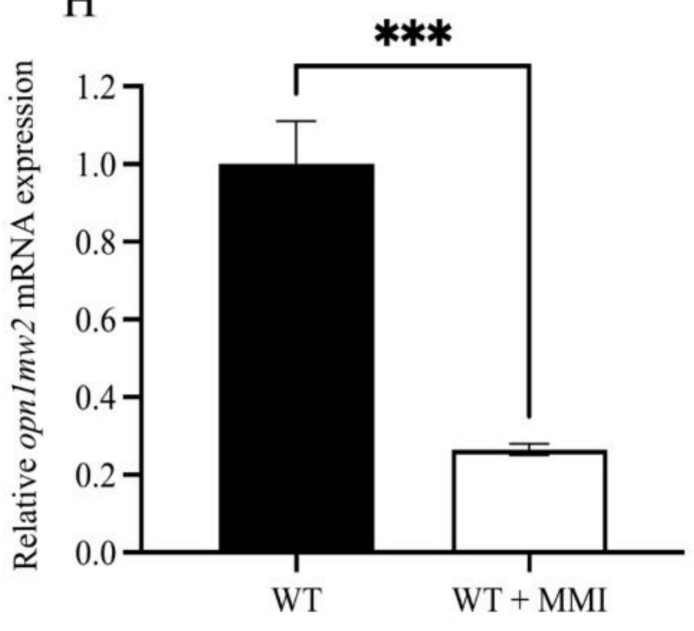

Figure 2. The expression of opn1mw2 is reduced in mct8-deficient larvae. (A-D) Ventral $(\mathbf{A}, \mathbf{C})$ and lateral (B,D) views of the spatial expression pattern of opn1mw 2 mRNA in $3 \mathrm{dpf}$ WT $(\mathbf{A}, \mathbf{B})$ and $m c t 8$ $-/-(\mathbf{C}, \mathbf{D})$ larvae. Scale bar $=300 \mu \mathrm{m}$. (B-E) The relative levels of opn1mw2 mRNA were determined using qRT-PCR. (E) Expression levels in 3, 4, and $6 \mathrm{dpf}$ mct $8-/-$ and WT sibling larvae $(n=5$ batches of larvae for each group). (F) Expression levels in $6 \mathrm{dpf} m c t 8^{-25 b p}-/-$ larvae $(n=5$ batches of larvae for each group). (G) Expression levels in $3 \mathrm{dpf} m c t 8-/-$, WT siblings, and mct8 mRNA-injected $m c t 8-/-$ embryos ( $n=5$ batches of larvae for each group). (H) The expression levels of opn1mw2 in WT larvae treated with the TH inhibitor methimazole (MMI) ( $n=5$ batches of larvae for each group). Relative gene expression was normalized against $a c t b$ in all assays. Statistical significance determined by $t$-test: two-sample. ${ }^{*} p<0.05,{ }^{* *} p<0.01,{ }^{* * *} p<0.001,{ }^{* * * *} p<0.0001$. 
Considering that lack of Mct8 can affect TH transport, we tested whether THs regulate opn1mw2 expression. Larvae were treated with $6 \mathrm{nM}$ of the $\mathrm{TH}$ inhibitor methimazole (MMI) [32] over 4 consecutive days. Similar to the findings in mct8-/- larvae (Figure 2E-G), the expression of opn 1 mw 2 mRNA decreased by 3.84-fold (Figure $2 \mathrm{H}$ ) in MMI-treated $6 \mathrm{dpf}$ larvae, suggesting that THs can induce the expression of opn1mw2 and regulate the development of the visual system.

\subsection{The Number of Conjugated Eye Movements Is Reduced in mct8 ${ }^{-25 b p}-/$ L Larvae}

The altered expression of many visual genes (Figure 1), such as the retinal opn1mw2 (Figure 2) in mct8- / - larvae, suggests that loss of Mct8 results in neuronal and behavioral deficiencies of the visual system. Thus, we studied visuomotor behavior in $m c t 8^{-25 b p}-/-$ larvae. A well-established assay in zebrafish larvae is the optokinetic reflex (OKR), which is induced as a response to a motion stimulus [33,34]. In all vertebrates, an OKR is a combination of slow eye movements following a moving stimulus (pursuits) and fast eye movements in the opposite direction to the stimulus (saccades) in both eyes simultaneously. Both phases are important for optimal visual acuity, orientation, and prey-capture behavior [35]. To monitor OKR in $m c t 8^{-25 b}+/-$ and their WT siblings, larvae were mounted in $3 \%$ methylcellulose, and their eyes were stimulated using rotating vertical black-andwhite stripes (Figure 3A). The amplitude and duration of the saccades and pursuits in both eyes were quantified (Figure 3B,C). Notably, the number of saccades and pursuits reduced in $m c t 8^{-25 b p}-/-$ larvae (Figure 3D,E), while the amplitude and velocity of the saccades did not change (Figure $3 F, G$ ). Analyzing the same parameters, no differences were found between the left and right eyes. These results show that although the pattern of the saccades and pursuits seems normal, the rate of conjugated eye movement is reduced in $m c t 8^{-25 b p}-/-$ larvae.

\subsection{Altered Spontaneous Neuronal Activity in the Pretectum of mct8 $8^{-25 b p}-/$ - Larvae}

The abnormal conjugated eye movement found in $m c t 8^{-25 b p}-/$ - larvae elicited us to study the activity of neurons in the pretectum area. In vertebrates, the pretectum regulates visual neuronal pathways such as the OKR [36,37]. Two-photon live imaging of the genetically encoded calcium indicator GCaMP6s was used to monitor neuronal activity in the pretectum of $6 \mathrm{dpf}\left[m c t 8^{-25 b p}-/-\times \operatorname{tg}(\mathrm{HuC}: \mathrm{H} 2 \mathrm{~B}-\mathrm{GCaMP} 6 \mathrm{~s})\right]$ and their $\operatorname{tg}(\mathrm{HuC}: \mathrm{H} 2 \mathrm{~B}-$ GCaMP6s) siblings (Figure 4A-C). Calculation of the average relative fluorescence variation $(\triangle \mathrm{F} / \mathrm{F})$ per single neuron showed increased activity in $\left[\mathrm{mcts}^{-25 b p}-/-\times \operatorname{tg}(\mathrm{HuC}: \mathrm{H} 2 \mathrm{~B}-\right.$ GCaMP6s)] larvae (Figure 4D). This result coincides with a decrease in the frequency of $\mathrm{Ca}^{2+}$ events and the increase in average maximum amplitude in single neurons of [mct8 $\left.{ }^{-25 b p}-/-\times \operatorname{tg}(H u C: H 2 B-G C a M P 6 s)\right]$ larvae (Figure 4E,F, respectively). The average duration of each $\mathrm{Ca}^{2+}$ event did not change (Figure 4G). Altogether, these results show that the activity of pretectal neurons is higher and slower in $m c t 8^{-25 b p}-/-$ larvae. These deficiencies in pretectal activity are associated with reduced OKR and altered expression of genes regulating the visual system, including the opsin gene opn1mw2, in Mct8-deficient zebrafish. 
A

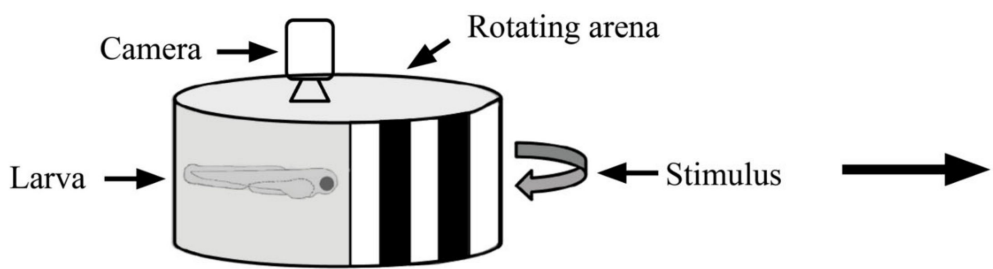

B
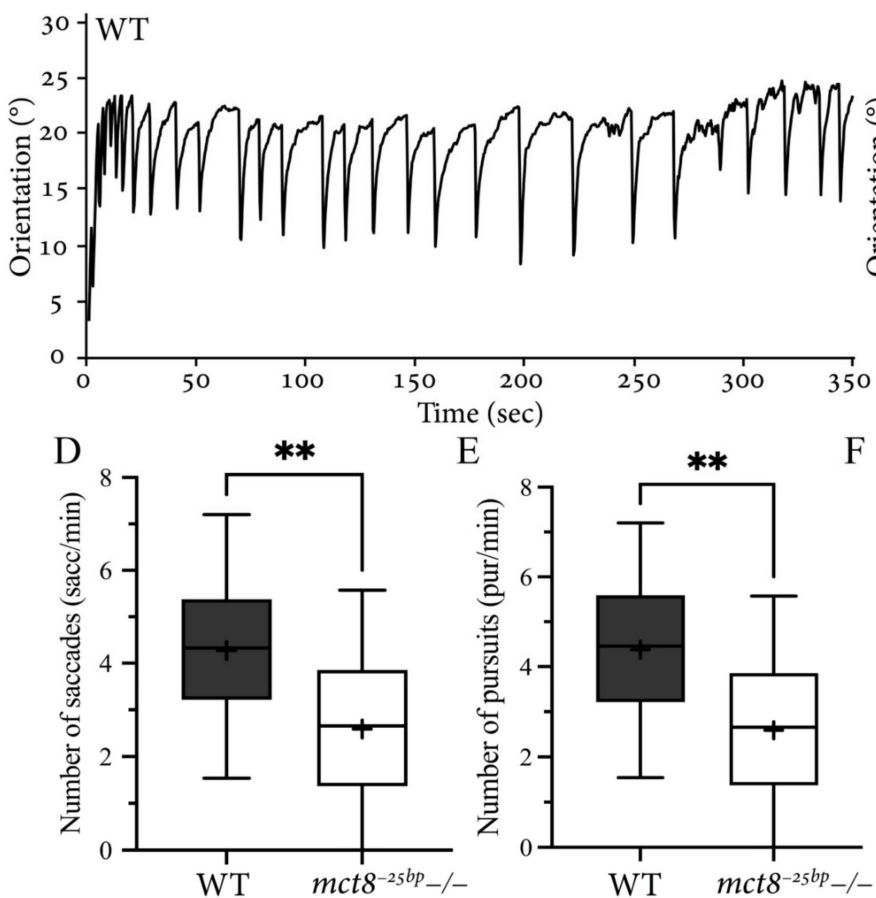

$\mathrm{F}$
$\mathrm{C}$
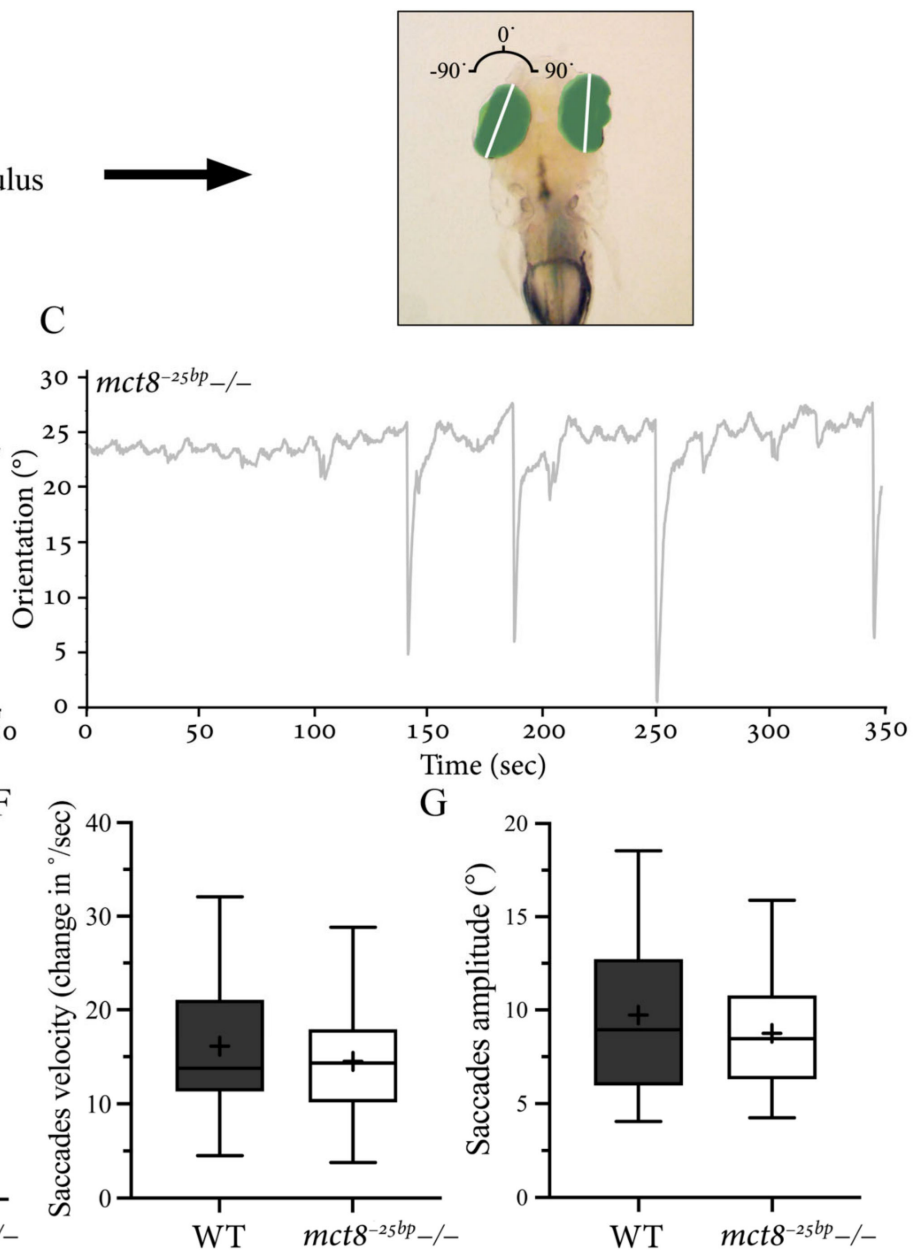

G

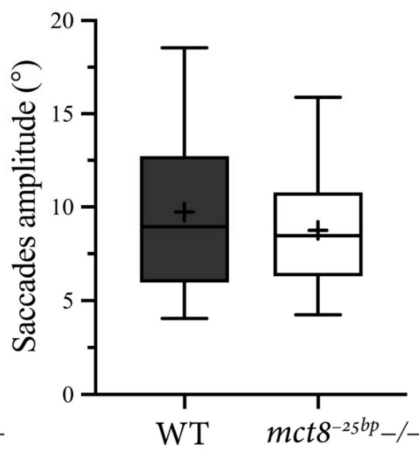

Figure 3. Altered visuomotor behavior in $m c t 8^{-25 b p}-/$ - larvae. (A) Experimental optokinetic reflex (OKR) setup. Video tracking of the eyes under the stimulus of moving vertical black-and-white stripes. The eyes (green region) were distinguished from the background, and the angular orientation of the long axis of each eye (white line) was analyzed. Clockwise and counterclockwise eye orientation was defined as positive and negative angles, respectively. $(B, C)$ The representative curve of the average dynamic orientation of both eyes in $6 \mathrm{dpf}$ WT (B) and $m c t 8^{-25 b p}-/-(\mathbf{C})$ larvae. (D-G) Box plots demonstrate the number, amplitude, and velocity of saccades, as well as the number of pursuits in $m c t 8^{-25 b p}-/-(n=17)$ and WT sibling $(n=18)$ larvae. The ' + ' sign shows the mean. Statistical significance was determined by Mann-Whitney U test. ${ }^{* *}(p<0.01)$. 

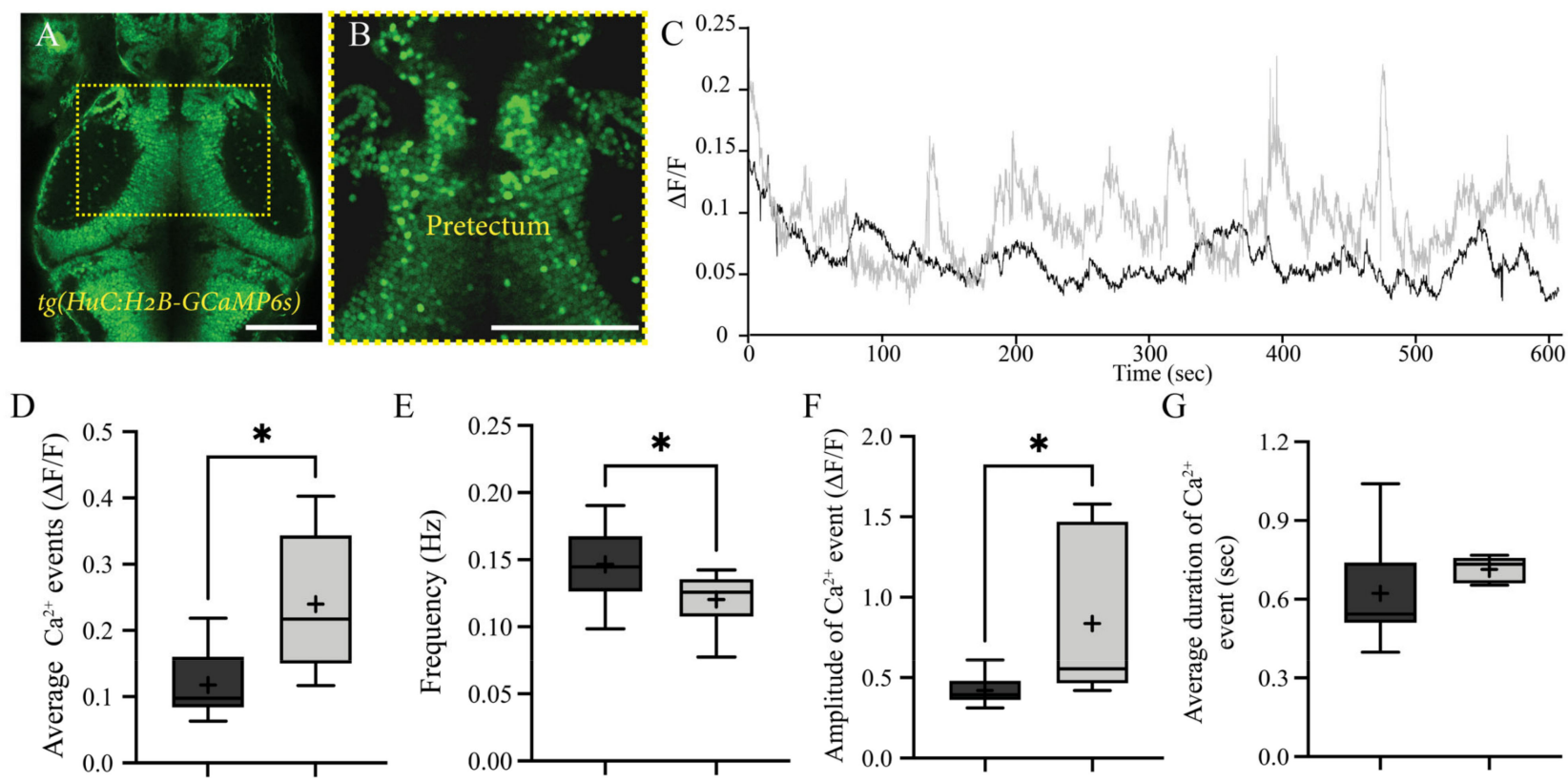

$\operatorname{tg}(\mathrm{HuC:H} 2 \mathrm{~B}-\mathrm{GCaMP} 6 \mathrm{~s})$

$m c t 8^{-25 b p}-/-\mathrm{X} \operatorname{tg}\left(\mathrm{HuC}: \mathrm{H}_{2} B-G C a M P 6 s\right)$

Figure 4. Stronger and slower neuronal activity in the pretectum area in $m c t 8^{-25 b p}-/$ - larvae. (A) Dorsal view of $\operatorname{tg}(\mathrm{HuC}: H 2 B-G C a M P 6 s) 6 \mathrm{dpf}$ larva (head pointing to the top). The dashed yellow square marks the enlarged view of the pretectum shown in (B). Scale bar $=50 \mu \mathrm{m}$. (C) Average relative fluorescence variation $(\Delta \mathrm{F} / \mathrm{F})$ activity of $\left[m c t 8^{-25 b p}-/-\times \operatorname{tg}(\mathrm{HuC}: H 2 B-G C a M P 6 s)\right]$ (grey) and their $\operatorname{tg}(\mathrm{HuC}: \mathrm{H} 2 \mathrm{~B}-\mathrm{GCaMP} 6 \mathrm{~s})$-siblings (black). (D-G) Changes in single-cell $\mathrm{Ca}^{2+}$ events are presented by the average number of events (D), frequency (E), amplitude (F) and duration $(\mathbf{G})$. The ' + ' sign shows the mean. $\operatorname{tg}(H u C: H 2 B-G C a M P 6 s)$-siblings: $\left.n=9,\left[m c t 8^{-25 b p}-/-\times \operatorname{tg}(H u C: H 2 B-G C a M P 6 s)\right]: n=6\right)$. Statistical significance was determined by Mann-Whitney U test. ${ }^{*}(p<0.05)$.

\section{Discussion}

THs are vital to the function of various essential processes, including cell growth and differentiation, as well as the development of the nervous system [1]. Insufficient transport of THs into the cells due to a mutation in the MCT8 transporter causes severe intellectual and motoric disability. We performed whole transcriptome sequencing, live imaging of neuronal activity, and behavioral experiments in a zebrafish model for MCT8-deficiency. The results identified differentially expressed genes, including a reduction in the mRNA levels of opn $1 m w 2$ and decreased conjugated eye movement. In addition, imaging of spontaneous neuronal activity in the pretectum revealed slower and stronger $\mathrm{Ca}^{2+}$ events in Mct8-deficient larvae. The results suggest genetic and neurological mechanisms that can regulate the abnormal function of the visual system in Mct8-deficiency.

The transcriptome profiling of $m c t 8-/-$ larvae revealed dozens of differentially expressed genes. Primarily, the expression of vision-related genes was altered, including reduced opn1mw2 mRNA levels, which are expressed in the retina [38]. This reduced expression is likely due to insufficient levels of THs in the cells, because pharmacological inhibition of TH synthesis resulted in reduced opn1mw2 expression in WT zebrafish larvae. This interaction between the thyroid system, opsins, and the visual system was observed in additional vertebrates. For example, TH controls adult cone opsin expression in mice [39]. $\mathrm{TH}$ receptors are expressed in the retina of early-stage chick embryos [40], and impaired cells were found in the retina of a hypothyroid rat [41]. In addition, supporting our findings in $m c t 8$ mutant zebrafish, alteration in retinal precursor cells affected the cone function in MCT8-knockdown chickens [42]. Transcriptome analysis in mct8 Morpholinoinjected $25 \mathrm{~h}$ post-fertilization (hpf) embryos revealed hundreds of differentially expressed 
genes. Among them, the expression of the vision-related gene rorab was reduced in $m c t 8$ Morpholino-injected embryos, suggesting that maternal $\mathrm{TH}$ regulates the expression of rorab and the development of the eyes [28]. The reduced expression of rorab may also be associated with the neurological deficiencies observed in $m c t 8-/-6 \mathrm{dpf}$ larvae. The results of this work link TH function with opn1mw2 expression in Mct8-deficient zebrafish and could be tested also in mammals.

The effect of Mct8 on visual gene expression, specifically the reduced expression of opn1mw2, suggests that the function of the eyes and visual brain nuclei is deficient. The $\mathrm{OKR}$ is a hallmark visual process in all vertebrates ranging from fish to humans [43]. In $m c t 8^{-25 b p}-/-$ larvae, we found a reduced number of saccades and pursuits. Similarly, a mutation in $m f r p$, a gene associated with retinal degeneration, reduced the number of saccades in zebrafish mutant [44]. These results suggest that reduced expression of opn1mw2 combined with altered expression of array of visual genes can cause abnormal OKR behavior.

The OKR deficiencies could reflect an abnormal function of the visual pathway from the eye to the brain. Optic flow directions are processed by direction-sensitive neurons, which are abundant in the zebrafish pretectum [45]. Similarly, the activity of pretectal neurons is associated with the onset of eye movements, including saccades and pursuits, in mammals [46]. Zebrafish pretectal activation induced conjugated eye movements while inhibition resulted in a lack of response, suggesting that the pretectum regulates the OKR movement [47]. In $m c t 8^{-25 b}-/$ - larvae, the amplitude of $\mathrm{Ca}^{2+}$ events increased, while the frequency decreased in the pretectum. Taking into account that most neurons in the pretectum are tuned to binocular directional movements $[48,49]$, lack of Mct8 may alter their development and function, resulting in dysregulated conjugating eye movements.

The abnormalities in the visual system of MCT8-deficiency patients have not been thoroughly studied. This study associates changes in visual gene expression with altered neuronal activity in the pretectum and abnormal OKR behavior in zebrafish model for MCT8-deficiency. Future functional research of the specific genes using gain- and lossof-function techniques, which are well established in zebrafish [26,50], combined with simultaneous monitoring of eye movement and neuronal activity, is expected to elucidate the underlined mechanism of MCT8-deficiency. In addition, live imaging of the neuronal response to visual stimulus in the entire brain [51-53] of the transparent $m c t 8^{-25 b p}-/-$ larvae could provide important insights to understand the effect of Mct8 on the activity of compatible neuronal circuits. Future experiments in the $m c t 8^{-25 b p}-/-$ zebrafish model, which will combine functional assays with pharmacological and genetic treatments [25,54-58] could lead to the development of a therapeutic strategy to MCT8-deficiency and other TH resistance disorders.

\section{Materials \& Methods}

\subsection{Zebrafish Husbandry, Mutant, and Transgenic Lines}

Adult zebrafish were raised and maintained in fully automated zebrafish housing systems (Aquazone, Zofit, Israel; temperature $28 \pm 0.5^{\circ} \mathrm{C}, \mathrm{pH} 7.0$, conductivity $500 \mu \mathrm{S}$ ) under $14 \mathrm{~h}$ light/10 $\mathrm{h}$ dark cycles and fed twice a day. Embryos were produced by natural spawning and raised in egg-water containing methylene blue $(0.3 \mathrm{ppm})$ in a light-controlled incubator at $28 \pm 0.5^{\circ} \mathrm{C}$, as previously described [59].

In this study, we used the previously established mct8-/- line [23] and the $\operatorname{tg}\left(\mathrm{HuC}: \mathrm{H}_{2} \mathrm{~B}-\right.$ GCaMP6s) line (also named tg(elavl3:H2B-GCaMP6s)) [60]. All animal protocols were reviewed and approved by the Bar-Ilan University Bioethics Committee.

The CRISPR system [61] was used to establish the $m c t 8^{-25 b p}-/$ - line. The Cas 9 mRNA was transcribed using the Cas9 expression vector (MLM3613, Addgene \#42251, Watertown, MA, USA) digested with PmeI and the mMESSAGE mMACHINE T7 ULTRA Kit (Life Technologies, Grand Island, NY, USA), and poly-A tailing was added using Poly(A) Tailing Kit (Ambion ${ }^{\circledR}$, Life Technologies, Grand Island, NY, USA). Annealed oligonucleotides (5'-TAGGTGCAGGCGCTGCTGGCCC-3' ${ }^{\prime}$ and 5'-AAACGGGCCAGCAGCGCCTGCA-3'), 
designed by the ZiFiT Targeter website (http:/ / zifit.partners.org/, accessed on 9 March 2019) to target the specific genomic site ( $5^{\prime}$-GGTGCAGGCGCTGCTGGCCC- $\left.3^{\prime}\right)$ in the third exon of the $m c t 8$ gene, were cloned into BsaI-digested gRNA expression vector (pDR274, Addgene \#42250, Watertown, MA, USA). sgRNA were transcribed using the DraI-digested gRNA expression vectors as templates and the RNA synthesis protocol (\#M0255, New England BioLabs Inc., Ipswich, MA, USA). Approximately $300 \mathrm{ng} / \mu \mathrm{L}$ of Cas9 mRNA and $15 \mathrm{ng} / \mu \mathrm{L}$ of sgRNA were co-injected to one-cell stage WT embryos. These mosaic embryos were raised to adulthood and out-crossed with WT fish to identify F0 founder fish. F1 heterozygous fish, which carry a 25 bp deletion mutation in the targeted site, were identified by PCR using the following primers: $5^{\prime}$-GCTGCGGCTCCTCGTTTGCATT- $3^{\prime}$ and 5'-GCACAGCAGTGGCGACGCCAAAG-3' ${ }^{\prime}$, and sequencing and selected F1 individuals were out-crossed with WT fish. The F2 heterozygous progeny were inter-crossed to generate the homozygous $m c t 8^{-25 b p}-/-$ line.

\subsection{Whole Transcriptome RNA-seq and Pathway Analysis}

Total RNA was extracted from three groups of $6 \mathrm{dpf}$ WT and mct8-/ - zebrafish (30 larvae per sample in a total of 6 samples), using the Direct-zol RNA MiniPrep Kit (Zymo Research Corporation) according to the manufacturer's protocol. The quality and quantity of each RNA sample were assessed by Agilent's 2100 Bioanalyzer 6000 Pico Kit (Agilent Technologies, Santa Clara, CA, USA). One $\mu \mathrm{g}$ of total RNA was used as input for preparations of RNA libraries using TrueSeq RNA Library Prep Kit v2 (Illumina, San Diego, CA, USA) according to the manufacturer's protocol. Six libraries were loaded on one lane of an Illumina HiSeq2500 instrument 100 bp paired-end run at the Technion Genome Center. Pair-end RNA-seq protocol was used, yielding about 21-35 million paired reads per sample. Paired-end reads were aligned to the zebrafish genome $(\mathrm{Zv} 9)$ using the STAR RNA-seq aligner software (version STAR_2.3.0e) [62]. The STAR genome database was built with the ENSEMBL annotation file (release 77, Danio_rerio.Zv9.77.gtf). Only uniquely mapped genes were considered for further analysis. Raw read counts for 33737 Ensembl-annotated gene-level features were determined using HTSeq-count [63]. Differentially expressed genes were determined with the R Bioconductor package DESeq [64]. $p$-Values were corrected with Benjamini-Hochberg FDR procedure. Genes with adjusted $p$-values $<0.05$ and $\mid \log$ fold change $\mid>1$ were considered as differentially expressed.

This list was then submitted to the IPA software (www.ingenuity.com, accessed on 12 October 2021). The list is mapped by Ingenuity based on ortholog information for humans, mouse, and rat. Ingenuity uses public databases to determine significantly enriched canonical pathways from the gene list. A total of 56 significantly changed genes were mapped and included in the analysis. The significance of the pathways was determined from a $p$-value $<0.05$ of overlap, calculated using a right-tailed Fisher's exact test.

\subsection{Quantitative Real-Time PCR}

The relative mRNA levels of opn1mw2 (Ensembl number: ENSDARG00000044280), hdac10 (ENSDARG00000086458), rad51 (ENSDARG00000041411), kcnv2b (ENSDARG00000062906), draxin (ENSDARG00000058256) and actin (NCBI accession number: AY222742.1) were determined using qRT-PCR. Total mRNA was extracted from five groups of $m c t 8+/+$ and $m c t 8-/-6$ dpf larvae ( $n=5$ batches per group, $n=8-10$ larvae per batch), using Direct-zol RNA MiniPrep kit (Zymo Research Corporation) according to the manufacturer's instructions. One $\mu \mathrm{g}$ mRNA was reverse-transcribed using qScript cDNA SuperMix (Quanta BioSciences, Gaithersburg, MD, USA). Relative transcript levels were determined by the 7900HT Fast Real-Time PCR System (Applied Biosystems, Foster City, CA, USA). Triplicates of each cDNA sample were PCR-amplified using the PerfeCTa SYBR Green FastMix (Quanta BioSciences, Gaithersburg, MD, USA) and the following specific primers: opn 1mw2: $5^{\prime}$-TGGCAATTAATTCTACGCAG- $3^{\prime}$ and $5^{\prime}$-TTGCTGGTGTCTTCTTGGCA- $3^{\prime}$ hdac10: $5^{\prime}$-TCTGACTCTGGGAGATTGGG-3 ${ }^{\prime}$ and $5^{\prime}$-GGATTTTGATTGTGGACTGGG-3' $k c n v 2 b$ : 5'-CGAAGGAAATGCAGCCAAAG- ${ }^{\prime}$ and $5^{\prime}$-CGTCCCTAAAACCAACTTTACC- 
$3^{\prime}$ draxin: $5^{\prime}$-CCGTGGCCTAAATAACAAGTG-3 ${ }^{\prime}$ and $5^{\prime}$-CTTGGTTGCTGTTGACTGATTC$3^{\prime}$ rad51: $5^{\prime}$-ATGGTCAGTGTTGAAGGCTC- $3^{\prime}$ and $5^{\prime}$-GGGTGGAGGTGAAGGAAAAG- ${ }^{\prime}$. The relative quantification of each gene expression was normalized against the housekeeping gene $a c t b$ : $5^{\prime}$-CAACAGGGAAAAGATGACACAG-3' and 5'-CATCACCAGAGTCCATCACG$3^{\prime}$ and subjected to the $\triangle \triangle C T$ method [65].

\subsection{Whole-Mount In Situ Hybridization (ISH) and Probe Preparation}

To prepare mRNA antisense probes, the full coding sequence of opn $1 m w 2$ was amplified. The PCR products were cloned into a pCRII-TOPO (Invitrogen, Carlsbad, CA, USA), which served as a template to transcribe digoxigenin-labeled antisense mRNA probes for opn $1 m w 2$. At $3 \mathrm{dpf}$, WT sibling larvae were fixed in $4 \%$ paraformaldehyde overnight at $4{ }^{\circ} \mathrm{C}$ and stored in $100 \%$ methanol. The location and level of mRNA expression were detected by whole-mount ISH, as described previously [66]. Each sample was incubated overnight with DIG-AP antibody (Roche, Basel, Switzerland), diluted to 1:2500, and then stained with $\mathrm{BM}$ purple (Roche, Basel, Switzerland). The reaction was terminated after being washed 3 times with PBT.

\subsection{Pharmacological and Transient Expression Assays}

Stock solution of $250 \mathrm{mM}$ MMI in $12.5 \%$ ethanol was used for TH inhibition assays in $52 \mathrm{hpf}$ embryos, which were placed in $25 \mathrm{ml}$ water containing final concentration of $6 \mathrm{nM}$ MMI (CAS-RN 60-56-0, purity $\geq 99 \%$, Sigma-Aldrich, St. Louis, MO, USA) or $0.07 \%$ ethanol as a control. At $6 \mathrm{dpf}$, larvae were sampled and subjected to quantification of opn1mw2 expression. In rescue experiments, $2 \mu \mathrm{L}$ of in vitro transcribed $m c t 8 \mathrm{mRNA}(100 \mathrm{ng} / \mu \mathrm{L})$ was microinjected into $m c t 8-/-$ embryos at the one-cell stage. Preparation of $m c t 8 \mathrm{mRNA}$ was performed as previously described [23].

\subsection{Imaging and Image Analysis}

Larvae stained with RNA probes were imaged using an epifluorescent stereomicroscope (Leica M165FC, Wetzlar, Germany). All images were taken using Leica Application Suite imaging software V3.7 (Leica, Wetzlar, Germany).

Imaging of neuronal activity in the pretectal area was conducted on $6 \mathrm{dpf}$ larvae, mounted with $1.5 \%$ low-melting-point agarose. Imaging was performed using a Zeiss LSM710 upright confocal/two-photon microscope (Zeiss, Oberkochen, Germany) with $\times 20$, 1.0 NA objective and the Mai-Tai 2-photon laser (Spectra-Physics, Santa Clara, CA, USA), tuned to $920 \mathrm{~nm}$ excitation wavelength. Half-hour movies (approximately 7000 frames) were taken at a speed of $\sim 4.12$ frames per second (fps), using an image resolution of $256 \times 256$ pixels $\left(\sim 0.223-\mathrm{mm}^{2}\right.$ optical plane). All images were processed using ImageJ (National Institutes of Health, Bethesda, MD, USA).

\subsection{OKR Assay}

OKR experiments were carried out using a custom-made device. The device is composed of a portable rotating drum placed above a light source. The interior of the drum contains black-and-white vertical stripes $(\sim 0.7 \mathrm{~cm}$ in width) as a stimulus. The drum rotates using an electrical motor. The $6 \mathrm{dpf}$ larvae were fixed in 3\% methylcellulose, and placed in a $5.5 \mathrm{~cm}$ petri dish inside the drum, while the stripes were turning clockwise. The eye movements of the larvae were recorded for $350 \mathrm{~s}$ in $2.85 \mathrm{~Hz}$, with an epifluorescent stereomicroscope (Leica M165FC, Wetzlar, Germany) equipped with an AmScope $10 \mathrm{MP}$ C-Mount Microscope Camera MU1000, and then analyzed using the AmScope v4.8.1 software (AmScope, Irvine, CA, USA). Experiments were conducted blindly to fish genotype, and each larva was genotyped following the video recording. Eye movement properties were detected using an open-source MATLAB program [67]. This data were then analyzed in a custom MATLAB software based on a previously published script [51], and saccades and pursuits were defined based on a threshold of amplitude and velocity. 


\subsection{Genotyping}

Genotyping of $m c t 8^{-25 b p}-/$ - zebrafish was conducted as follows. Genomic DNA was extracted from larvae, then incubated in $100 \mu \mathrm{L}$ of $50 \mathrm{nM} \mathrm{NaOH}$ at $95^{\circ} \mathrm{C}$ for $20 \mathrm{~min}$, and then kept on ice. Next, $10 \mu \mathrm{L}$ of Tris $(\mathrm{pH}=8)$ was added, and the sample was subjected to 30 -s vortex treatment and 2 min spinning at 12,000 relative centrifugal force (RCF). The extracted genomic DNA was then amplified by PCR using the following primers: 5'-AAACAGCACAGCAGTGGCGACG- ${ }^{\prime}$ and 5'-GACTCTGGGTCTCTGGTACTTCAC- ${ }^{\prime}$. PCR product was then run on $3 \%$ agarose gel for $90 \mathrm{~min}$. PCR amplification resulted in fragments of $454 \mathrm{bp}$ in WT and $429 \mathrm{bp}$ in $m c t 8^{-25 b}-/$ - zebrafish. Selected PCR products were sequenced to validate the gel results. As expected, heterozygous fish showed two DNA fragments, indicating the presence of both mutated and WT mct 8 alleles.

\subsection{Data and Statistical Analysis}

Determination of sex in larval zebrafish before $8 \mathrm{dpf}$ cannot be identified [68], therefore larvae used in all experiments are of unknown sex. Bar graphs, box plots, as well as statistical analysis were generated using GraphPad Prism version 9.2.0 for macOS (GraphPad Software, San Diego, CA, USA). Quantification of $\triangle F / F$ in pretectum neurons was determined and produced using published MATLAB scripts [69]. $\mathrm{Ca}^{2+}$ events were determined by applying a threshold equal to two times the standard deviation of the baseline fluctuations in each cell. Analysis was applied on all fluctuations exceeding this threshold.

Supplementary Materials: The following supporting information can be downloaded at: https: //www.mdpi.com/article/10.3390/ijms23052464/s1.

Author Contributions: R.R. and L.A. designed and assembled the experiments. R.R., A.T. and T.L.-G. performed and analyzed the experiments. D.Z. established the zebrafish mutant. I.L.-L. performed bioinformatical analysis. R.R. and L.A. generated the figures and wrote the paper with feedback from all other authors. All authors have read and agreed to the published version of the manuscript.

Funding: This work was supported by grants from the Sherman Foundation and the University of Technology Sydney (590262), the German-Israeli Foundation for Scientific Research and Development (GIF, I-1314-418.13/2015), and Foundation Jérôme Lejeune (1675). RR was supported by the Azrieli Foundation.

Institutional Review Board Statement: The animal study protocol was approved by the Ethics Committee of Bar Ilan University (protocol 18-02-2020).

Acknowledgments: We thank Auriane Duchemin and Germán Sumbre (IBENS, École normale supérieure, France) for sharing the script for neuronal activity and eye movement analysis. We wish to also thank Idan Elbaz for building the OKR device and Yael Laure for the English editing of the manuscript.

Conflicts of Interest: The authors declare no conflict of interest.

\section{References}

1. Bernal, J. Thyroid Hormones in Brain Development and Function. In Endotext; Feingold, K.R., Anawalt, B., Boyce, A., Chrousos, G., de Herder, W.W., Dhatariya, K., Dungan, K., Grossman, A., Hershman, J.M., Hofland, J., et al., Eds.; MDText.com, Inc.: South Dartmouth, MA, USA, 2000.

2. Weiss, R.E.; Refetoff, S. Effect of Thyroid Hormone On Growth: Lessons from the Syndrome of Resistance to Thyroid Hormone. Endocrinol. Metab. Clin. N. Am. 1996, 25, 719-730. [CrossRef]

3. Gruters, A.; Krude, H.; Biebermann, H. Molecular Genetic Defects in Congenital Hypothyroidism. Eur. J. Endocrinol. 2004, 151, U39-U44. [CrossRef] [PubMed]

4. Ausó, E.; Lavado-Autric, R.; Cuevas, E.; del Rey, F.E.; de Escobar, G.M.; Berbel, P. A Moderate and Transient Deficiency of Maternal Thyroid Function at the Beginning of Fetal Neocorticogenesis Alters Neuronal Migration. Endocrinology 2004, 145, 4037-4047. [CrossRef]

5. Friesema, E.C.H.; Ganguly, S.; Abdalla, A.; Fox, J.E.M.; Halestrap, A.P.; Visser, T.J. Identification of Monocarboxylate Transporter 8 as a Specific Thyroid Hormone Transporter. J. Biol. Chem. 2003, 278, 40128-40135. [CrossRef] [PubMed] 
6. Dumitrescu, A.M.; Liao, X.-H.; Best, T.B.; Brockmann, K.; Refetoff, S. A Novel Syndrome Combining Thyroid and Neurological Abnormalities Is Associated with Mutations in a Monocarboxylate Transporter Gene. Am. J. Hum. Genet. 2004, 74, 168-175. [CrossRef] [PubMed]

7. Heuer, H.; Visser, T.J. Minireview: Pathophysiological Importance of Thyroid Hormone Transporters. Endocrinology 2009, 150, 1078-1083. [CrossRef] [PubMed]

8. Brockmann, K.; Dumitrescu, A.M.; Best, T.T.; Hanefeld, F.; Refetoff, S. X-Linked Paroxysmal Dyskinesia and Severe Global Retardation Caused by Defective MCT8 Gene. J. Neurol. 2005, 252, 663-666. [CrossRef] [PubMed]

9. Biebermann, H.; Ambrugger, P.; Tarnow, P.; von Moers, A.; Schweizer, U.; Grueters, A. Extended Clinical Phenotype, Endocrine Investigations and Functional Studies of a Loss-of-Function Mutation A150V in the Thyroid Hormone Specific Transporter MCT8. Eur. J. Endocrinol. 2005, 153, 359-366. [CrossRef] [PubMed]

10. Findlay, J.B.; Pappin, D.J. The Opsin Family of Proteins. Biochem. J. 1986, 238, 625-642. [CrossRef]

11. Koyanagi, M.; Takano, K.; Tsukamoto, H.; Ohtsu, K.; Tokunaga, F.; Terakita, A. Jellyfish Vision Starts with CAMP Signaling Mediated by Opsin-Gs Cascade. Proc. Natl. Acad. Sci. USA 2008, 105, 15576-15580. [CrossRef]

12. Roberts, M.R.; Srinivas, M.; Forrest, D.; de Escobar, G.M.; Reh, T.A. Making the Gradient: Thyroid Hormone Regulates Cone Opsin Expression in the Developing Mouse Retina. Proc. Natl. Acad. Sci. USA 2006, 103, 6218-6223. [CrossRef]

13. Pessôa, C.N.; Santiago, L.A.; Santiago, D.A.; Machado, D.S.; Rocha, F.A.F.; Ventura, D.F.; Hokoç, J.N.; Pazos-Moura, C.C.; Wondisford, F.E.; Gardino, P.F.; et al. Thyroid Hormone Action Is Required for Normal Cone Opsin Expression during Mouse Retinal Development. Investig. Ophthalmol. Vis. Sci. 2008, 49, 2039-2045. [CrossRef] [PubMed]

14. Eldred, K.C.; Hadyniak, S.E.; Hussey, K.A.; Brenerman, B.; Zhang, P.-W.; Chamling, X.; Sluch, V.M.; Welsbie, D.S.; Hattar, S.; Taylor, J.; et al. Thyroid Hormone Signaling Specifies Cone Subtypes in Human Retinal Organoids. Science 2018, 362, eaau6348. [CrossRef] [PubMed]

15. Mayerl, S.; Müller, J.; Bauer, R.; Richert, S.; Kassmann, C.M.; Darras, V.M.; Buder, K.; Boelen, A.; Visser, T.J.; Heuer, H. Transporters MCT8 and OATP1C1 Maintain Murine Brain Thyroid Hormone Homeostasis. J. Clin. Investig. 2014, 124, 1987-1999. [CrossRef]

16. Liao, X.-H.; Di Cosmo, C.; Dumitrescu, A.M.; Hernandez, A.; Van Sande, J.; St. Germain, D.L.; Weiss, R.E.; Galton, V.A.; Refetoff, S. Distinct Roles of Deiodinases on the Phenotype of Mct8 Defect: A Comparison of Eight Different Mouse Genotypes. Endocrinology 2011, 152, 1180-1191. [CrossRef] [PubMed]

17. Bárez-López, S.; Grijota-Martínez, C.; Ausó, E.; Fernández-de Frutos, M.; Montero-Pedrazuela, A.; Guadaño-Ferraz, A. Adult Mice Lacking Mct8 and Dio2 Proteins Present Alterations in Peripheral Thyroid Hormone Levels and Severe Brain and Motor Skill Impairments. Thyroid 2019, 29, 1669-1682. [CrossRef] [PubMed]

18. Wirth, E.K.; Roth, S.; Blechschmidt, C.; Hölter, S.M.; Becker, L.; Racz, I.; Zimmer, A.; Klopstock, T.; Gailus-Durner, V.; Fuchs, H.; et al. Neuronal 3',3,5-Triiodothyronine (T3) Uptake and Behavioral Phenotype of Mice Deficient in Mct8, the Neuronal T3 Transporter Mutated in Allan-Herndon-Dudley Syndrome. J. Neurosci. 2009, 29, 9439-9449. [CrossRef] [PubMed]

19. Dumitrescu, A.M.; Liao, X.-H.; Weiss, R.E.; Millen, K.; Refetoff, S. Tissue-Specific Thyroid Hormone Deprivation and Excess in Monocarboxylate Transporter (Mct) 8-Deficient Mice. Endocrinology 2006, 147, 4036-4043. [CrossRef]

20. Friesema, E.C.H.; Jansen, J.; Heuer, H.; Trajkovic, M.; Bauer, K.; Visser, T.J. Mechanisms of Disease: Psychomotor Retardation and High T3 Levels Caused by Mutations in Monocarboxylate Transporter 8. Nat. Clin. Pract. Endocrinol. Metab. 2006, 2, 512-523. [CrossRef]

21. Porazzi, P.; Calebiro, D.; Benato, F.; Tiso, N.; Persani, L. Thyroid Gland Development and Function in the Zebrafish Model. Mol. Cell. Endocrinol. 2009, 312, 14-23. [CrossRef]

22. Vancamp, P.; Houbrechts, A.M.; Darras, V.M. Insights from Zebrafish Deficiency Models to Understand the Impact of Local Thyroid Hormone Regulator Action on Early Development. Gen. Comp. Endocrinol. 2019, 279, 45-52. [CrossRef]

23. Campinho, M.A.; Saraiva, J.; Florindo, C.; Power, D.M. Maternal Thyroid Hormones Are Essential for Neural Development in Zebrafish. Mol. Endocrinol. 2014, 28, 1136-1149. [CrossRef]

24. Zada, D.; Tovin, A.; Lerer-Goldshtein, T.; Vatine, G.D.; Appelbaum, L. Altered Behavioral Performance and Live Imaging of Circuit-Specific Neural Deficiencies in a Zebrafish Model for Psychomotor Retardation. PLoS Genet. 2014, 10, e1004615. [CrossRef]

25. Zada, D.; Tovin, A.; Lerer-Goldshtein, T.; Appelbaum, L. Pharmacological Treatment and BBB-Targeted Genetic Therapy for MCT8-Dependent Hypomyelination in Zebrafish. Dis. Models Mech. 2016, 9, 1339-1348. [CrossRef]

26. Zada, D.; Blitz, E.; Appelbaum, L. Zebrafish-An Emerging Model to Explore Thyroid Hormone Transporters and Psychomotor Retardation. Mol. Cell. Endocrinol. 2017, 459, 53-58. [CrossRef]

27. Visser, W.E.; Swagemakers, S.M.A.; Őzgûr, Z.; Schot, R.; Verheijen, F.W.; van Ijcken, W.F.J.; van der Spek, P.J.; Visser, T.J. Transcriptional Profiling of Fibroblasts from Patients with Mutations in MCT8 and Comparative Analysis with the Human Brain Transcriptome. Hum. Mol. Genet. 2010, 19, 4189-4200. [CrossRef]

28. Silva, N.; Louro, B.; Trindade, M.; Power, D.M.; Campinho, M.A. Transcriptomics Reveal an Integrative Role for Maternal Thyroid Hormones during Zebrafish Embryogenesis. Sci. Rep. 2017, 7, 16657. [CrossRef]

29. Morte, B.; Gil-Ibañez, P.; Heuer, H.; Bernal, J. Brain Gene Expression in Systemic Hypothyroidism and Mouse Models of MCT8 Deficiency: The Mct8-Oatp1c1-Dio2 Triad. Thyroid 2021, 31, 985-993. [CrossRef]

30. Ramos-Lopez, E.; Kurylowicz, A.; Bednarczuk, T.; Paunkovic, J.; Seidl, C.; Badenhoop, K. Vitamin D Receptor Polymorphisms Are Associated with Graves' Disease in German and Polish But Not in Serbian Patients. Thyroid 2005, 15, 1125-1130. [CrossRef] 
31. Cook, I.; Wang, T.; Leyh, T.S. Tetrahydrobiopterin Regulates Monoamine Neurotransmitter Sulfonation. Proc. Natl. Acad. Sci. USA 2017, 114, E5317-E5324. [CrossRef]

32. Davidson, B.; Soodak, M.; Neary, J.T.; Strout, H.V.; Kieffer, J.D.; Mover, H.; Maloof, F. The Irreversible Inactivation of Thyroid Peroxidase by Methylmercaptoimidazole, Thiouracil, and Propylthiouracil in Vitro and Its Relationship to in Vivo Findings. Endocrinology 1978, 103, 871-882. [CrossRef]

33. Brockerhoff, S.E.; Hurley, J.B.; Janssen-Bienhold, U.; Neuhauss, S.C.; Driever, W.; Dowling, J.E. A Behavioral Screen for Isolating Zebrafish Mutants with Visual System Defects. Proc. Natl. Acad. Sci. USA 1995, 92, 10545-10549. [CrossRef]

34. Neuhauss, S.C.F.; Biehlmaier, O.; Seeliger, M.W.; Das, T.; Kohler, K.; Harris, W.A.; Baier, H. Genetic Disorders of Vision Revealed by a Behavioral Screen of 400 Essential Loci in Zebrafish. J. Neurosci. 1999, 19, 8603-8615. [CrossRef]

35. Huang, M.Y.-Y.; Neuhauss, S. The Optokinetic Response in Zebrafish and Its Applications. Front. Biosci. J. Virtual Libr. 2008, 13, 1899-1916. [CrossRef] [PubMed]

36. Wang, K.; Hinz, J.; Zhang, Y.; Thiele, T.R.; Arrenberg, A.B. Parallel Channels for Motion Feature Extraction in the Pretectum and Tectum of Larval Zebrafish. Cell Rep. 2020, 30, 442-453.e6. [CrossRef] [PubMed]

37. Reber, A.; Lannou, J.; Hess, B.J. Development of Optokinetic Neuronal Responses in the Pretectum and Horizontal Optokinetic Nystagmus in Unilaterally Enucleated Rats. Arch. Ital. Biol. 1989, 127, 225-242. [PubMed]

38. Tsujimura, T.; Masuda, R.; Ashino, R.; Kawamura, S. Spatially Differentiated Expression of Quadruplicated Green-Sensitive RH2 Opsin Genes in Zebrafish Is Determined by Proximal Regulatory Regions and Gene Order to the Locus Control Region. BMC Genet. 2015, 16, 130. [CrossRef]

39. Glaschke, A.; Weiland, J.; Turco, D.D.; Steiner, M.; Peichl, L.; Glösmann, M. Thyroid Hormone Controls Cone Opsin Expression in the Retina of Adult Rodents. J. Neurosci. 2011, 31, 4844-4851. [CrossRef]

40. Sjoberg, M.; Vennstrom, B.; Forrest, D. Thyroid Hormone Receptors in Chick Retinal Development: Differential Expression of MRNAs for Alpha and N-Terminal Variant Beta Receptors. Development 1992, 114, 39-47. [CrossRef]

41. Sevilla-Romero, E.; Muñoz, A.; Pinazo-Durán, M.D. Low Thyroid Hormone Levels Impair the Perinatal Development of the Rat Retina. ORE 2002, 34, 181-191. [CrossRef]

42. Vancamp, P.; Bourgeois, N.M.A.; Houbrechts, A.M.; Darras, V.M. Knockdown of the Thyroid Hormone Transporter MCT8 in Chicken Retinal Precursor Cells Hampers Early Retinal Development and Results in a Shift towards More UV/Blue Cones at the Expense of Green/Red Cones. Exp. Eye Res. 2019, 178, 135-147. [CrossRef] [PubMed]

43. Land, M.F. Eye Movements of Vertebrates and Their Relation to Eye Form and Function. J. Comp. Physiol. A 2015, 201, 195-214. [CrossRef] [PubMed]

44. Collery, R.F.; Volberding, P.J.; Bostrom, J.R.; Link, B.A.; Besharse, J.C. Loss of Zebrafish Mfrp Causes Nanophthalmia, Hyperopia, and Accumulation of Subretinal Macrophages. Investig. Ophthalmol. Vis. Sci. 2016, 57, 6805-6814. [CrossRef] [PubMed]

45. Wang, K.; Hinz, J.; Haikala, V.; Reiff, D.F.; Arrenberg, A.B. Selective Processing of All Rotational and Translational Optic Flow Directions in the Zebrafish Pretectum and Tectum. BMC Biol. 2019, 17, 29. [CrossRef]

46. Missal, M.; Coimbra, A.; Lefèvre, P.; Olivier, E. A Quantitative Analysis of the Correlations between Eye Movements and Neural Activity in the Pretectum. Exp. Brain Res. 2002, 143, 373-382. [CrossRef]

47. Kubo, F.; Hablitzel, B.; Dal Maschio, M.; Driever, W.; Baier, H.; Arrenberg, A.B. Functional Architecture of an Optic FlowResponsive Area That Drives Horizontal Eye Movements in Zebrafish. Neuron 2014, 81, 1344-1359. [CrossRef]

48. Naumann, E.A.; Fitzgerald, J.E.; Dunn, T.W.; Rihel, J.; Sompolinsky, H.; Engert, F. From Whole-Brain Data to Functional Circuit Models: The Zebrafish Optomotor Response. Cell 2016, 167, 947-960.e20. [CrossRef]

49. Wu, Y.; dal Maschio, M.; Kubo, F.; Baier, H. An Optical Illusion Pinpoints an Essential Circuit Node for Global Motion Processing Neuron 2020, 108, 722-734.e5. [CrossRef]

50. Levitas-Djerbi, T.; Appelbaum, L. Modeling Sleep and Neuropsychiatric Disorders in Zebrafish. Curr. Opin. Neurobiol. 2017, 44, 89-93. [CrossRef]

51. Pérez-Schuster, V.; Kulkarni, A.; Nouvian, M.; Romano, S.A.; Lygdas, K.; Jouary, A.; Dipoppa, M.; Pietri, T.; Haudrechy, M.; Candat, V.; et al. Sustained Rhythmic Brain Activity Underlies Visual Motion Perception in Zebrafish. Cell Rep. 2016, 17, 1098-1112. [CrossRef]

52. Fernandes, A.M.; Mearns, D.S.; Donovan, J.C.; Larsch, J.; Helmbrecht, T.O.; Kölsch, Y.; Laurell, E.; Kawakami, K.; dal Maschio, M.; Baier, H. Neural Circuitry for Stimulus Selection in the Zebrafish Visual System. Neuron 2021, 109, 805-822.e6. [CrossRef]

53. Förster, D.; Helmbrecht, T.O.; Mearns, D.S.; Jordan, L.; Mokayes, N.; Baier, H. Retinotectal Circuitry of Larval Zebrafish Is Adapted to Detection and Pursuit of Prey. eLife 2020, 9, e58596. [CrossRef]

54. Admati, I.; Wasserman-Bartov, T.; Tovin, A.; Rozenblat, R.; Blitz, E.; Zada, D.; Lerer-Goldshtein, T.; Appelbaum, L. Neural Alterations and Hyperactivity of the Hypothalamic-Pituitary-Thyroid Axis in Oatp1c1 Deficiency. Thyroid 2020, 30, 161-174. [CrossRef]

55. Grijota-Martínez, C.; Bárez-López, S.; Gómez-Andrés, D.; Guadaño-Ferraz, A. MCT8 Deficiency: The Road to Therapies for a Rare Disease. Front. Neurosci. 2020, 14, 380. [CrossRef]

56. Van Geest, F.S.; Gunhanlar, N.; Groeneweg, S.; Visser, W.E. Monocarboxylate Transporter 8 Deficiency: From Pathophysiological Understanding to Therapy Development. Front. Endocrinol. 2021, 12, 723750. [CrossRef] 
57. Iwayama, H.; Liao, X.-H.; Braun, L.; Bárez-López, S.; Kaspar, B.; Weiss, R.E.; Dumitrescu, A.M.; Guadaño-Ferraz, A.; Refetoff, S. Adeno Associated Virus 9-Based Gene Therapy Delivers a Functional Monocarboxylate Transporter 8, Improving Thyroid Hormone Availability to the Brain of Mct8-Deficient Mice. Thyroid 2016, 26, 1311-1319. [CrossRef]

58. Vatine, G.D.; Al-Ahmad, A.; Barriga, B.K.; Svendsen, S.; Salim, A.; Garcia, L.; Garcia, V.J.; Ho, R.; Yucer, N.; Qian, T.; et al. Modeling Psychomotor Retardation Using IPSCs from MCT8-Deficient Patients Indicates a Prominent Role for the Blood-Brain Barrier. Cell Stem Cell 2017, 20, 831-843.e5. [CrossRef]

59. Elbaz, I.; Yelin-Bekerman, L.; Nicenboim, J.; Vatine, G.; Appelbaum, L. Genetic Ablation of Hypocretin Neurons Alters Behavioral State Transitions in Zebrafish. J. Neurosci. 2012, 32, 12961-12972. [CrossRef]

60. Freeman, J.; Vladimirov, N.; Kawashima, T.; Mu, Y.; Sofroniew, N.J.; Bennett, D.V.; Rosen, J.; Yang, C.-T.; Looger, L.L.; Ahrens, M.B. Mapping Brain Activity at Scale with Cluster Computing. Nat. Methods 2014, 11, 941-950. [CrossRef]

61. Hwang, W.Y.; Fu, Y.; Reyon, D.; Maeder, M.L.; Tsai, S.Q.; Sander, J.D.; Peterson, R.T.; Yeh, J.-R.J.; Joung, J.K. Efficient Genome Editing in Zebrafish Using a CRISPR-Cas System. Nat. Biotechnol. 2013, 31, 227-229. [CrossRef]

62. Dobin, A.; Davis, C.A.; Schlesinger, F.; Drenkow, J.; Zaleski, C.; Jha, S.; Batut, P.; Chaisson, M.; Gingeras, T.R. STAR: Ultrafast Universal RNA-Seq Aligner. Bioinformatics 2013, 29, 15-21. [CrossRef] [PubMed]

63. Anders, S.; Pyl, P.T.; Huber, W. HTSeq-A Python Framework to Work with High-Throughput Sequencing Data. Bioinformatics 2015, 31, 166-169. [CrossRef] [PubMed]

64. Anders, S.; Huber, W. Differential Expression Analysis for Sequence Count Data. Nat. Prec. 2010, 1. [CrossRef]

65. Schmittgen, T.D.; Livak, K.J. Analyzing Real-Time PCR Data by the Comparative CT Method. Nat. Protoc. 2008, 3, 1101-1108. [CrossRef]

66. Yelin-Bekerman, L.; Elbaz, I.; Diber, A.; Dahary, D.; Gibbs-Bar, L.; Alon, S.; Lerer-Goldshtein, T.; Appelbaum, L. Hypocretin Neuron-Specific Transcriptome Profiling Identifies the Sleep Modulator Kcnh4a. eLife 2015, 4, e08638. [CrossRef]

67. Scheetz, S.D.; Shao, E.; Zhou, Y.; Cario, C.L.; Bai, Q.; Burton, E.A. An Open-Source Method to Analyze Optokinetic Reflex Responses in Larval Zebrafish. J. Neurosci. Methods 2018, 293, 329-337. [CrossRef]

68. Kossack, M.E.; Draper, B.W. Genetic Regulation of Sex Determination and Maintenance in Zebrafish (Danio Rerio). Curr. Top. Dev. Biol. 2019, 134, 119-149. [CrossRef]

69. Romano, S.A.; Pérez-Schuster, V.; Jouary, A.; Boulanger-Weill, J.; Candeo, A.; Pietri, T.; Sumbre, G. An Integrated Calcium Imaging Processing Toolbox for the Analysis of Neuronal Population Dynamics. PLoS Comput. Biol. 2017, 13, e1005526. [CrossRef] 